\title{
Stigmatisasi dan Pembentukan Solidaritas Kolektif dalam Perkembangan COVID-19 di Jawa Timur
}

\author{
${ }^{1}$ Suprapto \\ Ilmu Pemerintahan, Fakultas IImu Sosial dan Ilmu Politik, \\ Universitas Islam Majapahit \\ suprapto@unim.ac.id \\ ${ }^{2}$ Ahmad Hasan Afandi \\ Ilmu Pemerintahan, Fakultas Ilmu Sosial dan Ilmu Politik, \\ Universitas Islam Majapahit \\ Mahasiswa Program Doktoral Sosiologi, Universitas Brawijaya \\ hasan.pita@gmail.com
}

Keywords:

Stigma; COVID19; Collective Solidarity;

Stigma; COVID19;

Solidaritas Kolektif

BRAWIJAYA JOURNAL of SOCIAL SCIENCE

Vol. 1 ,No. 1,2021

DOI:

https://doi.org/10. 21776/ub.bjss.2021 .001 .01 .3

Submitted:2021-11-16 Accepted:2021-12-01

\section{Abstract}

Stigma develops from places that are vulnerable to the spread of COVID-19. Stigma has an impact on socio-psychological conditions that cause mass complaints. This stigma causes people to feel panicked and eventually leads to paranoia. In accordance with the development of conditions related to COVID-19, this study aims to analyze the pattern of developing stigma and its anticipation pattern through the formation of collective solidarity. This research uses a mixed method approach. Data were analyzed and supported using SPSS 16 and Nvivo 12. Includes elements of social stigma, collective solidarity, anxiety, and attitudes to vaccines. The results show that there are several effects of stigma such as health risks, exclusion, anxiety, life discomfort, psychological disorders, reduced social and emotional capital, breaking of family ties and social solidarity that work as barriers to social welfare. The relationship between stigma and collective solidarity in this research is to fight misconceptions, misinformation and stigmatization, in which community members directly support each other, become volunteers, compose songs about COVID, hold lecture on the wisdom during the pandemic, and present humor that can strengthen the community and reduce the level of stigmatization in COVID-19 patients. In the formation of collective solidarity, namely using sympathetic narratives, communication methods that provide motivation to heal, mutually reinforcing attitudes, donation and sharing movements, strengthening social sensitivity, as well as active involvement of the private and public sectors. In the private and public sectors, especially for hospitals, this is done by allocating the state budget and providing better health management. 


\section{Abstrak}

Stigma berkembang dari tempat-tempat yang rentan atas penyebaran COVID19. Stigma berdampak pada keadaan sosial-psikologis yang menimbulkan keluhan massal. Stigma ini menimbulkan orang merasa panik dan akhirnya memunculkan sikap paranoid. Sesuai dengan kondisi perkembangan COVID19 , penelitian ini bertujuan menganalisis pola berkembangnya stigma dan pola antisipasinya melalui pembentukan solidaritas kolektif. Penelitian ini menggunakan pendekatan mixed method. Data dianalisis dan didukung menggunakan SPSS 16 dan Nvivo 12. Mencakup unsur stigma sosial, solidaritas kolektif, kecemasan, dan sikap untuk vaksin. Hasil penelitian menunjukkan bahwa terdapat beberapa efek dari stigma seperti risiko kesehatan, pengucilan, kecemasan, ketidaknyamanan hidup, gangguan psikologis, berkurangnya modal sosial dan modal emosional, putusnya ikatan keluarga dan solidaritas sosial yang bekerja sebagai penghalang kesejahteraan masyarakat. Keterkaitan stigma dan solidaritas kolektif pada penelitian ini yakni untuk melawan miskonsepsi, misinformasi dan stigmatisasi. Dimana masyarakat secara langsung saling memberi dukungan, menjadi relawan, penciptaan lagu tentang COVID, pengajian-pengajian tentang hikmah pandemi, dan pemunculan humor-humor yang dapat menguatkan masyarakat serta menurunkan tingkat stigmatisasi pada pasien COVID-19. Dalam pembentukan solidaritas kolektif yakni menggunakan narasi yang simpatik, cara komunikasi yang memberikan motivasi untuk sembuh, sikap saling menguatkan, gerakan donasi dan berbagi, penguatan kepekaan sosial, dan keterlibatan aktif dari sektor privat dan publik. Pada sektor privat dan publik lebih khusus untuk di rumah sakit dengan mengalokasikan anggaran negara dan untuk manajemen kesehatan.

\section{Pendahuluan}

Sepanjang sejarah, dunia telah mengalami pandemi yang telah menyebabkan rasa sakit, penderitaan, dan kematian yang luar biasa. Sementara manusia telah ulet dalam mengatasi pandemi semacam itu. Ribuan, bahkan jutaan nyawa telah hilang karena pandemi, kehilangan pekerjaan, dan ekonomi dan mengakibatkan resesi. Ketika para ilmuwan sedang bekerja keras mencari obat dan vaksin, virus tersebut memiliki pengaruh besar pada kehidupan sosial dan sikap, serta pada psikologi. Pandemi terus berdampak besar pada kehidupan sosial dan sikap yang menanamkan perasaan kesepian dan ketakutan dan pada saat yang sama memicu kasus depresi, stres, dan kecemasan.

Pandemi COVID-19 yang dimulai dari Wuhan, China, dan kini menyebar ke seluruh dunia. Hal ini ditularkan terutama oleh percikan pernapasan dan kontak dekat. Coronavirus telah ada cukup lama sekarang sebagai keluarga virus zoonosis yang bertanggung jawab atas berbagai penyakit seperti flu biasa dan infeksi pernapasan. Namun, novel coronavirus COVID-19 yang saat ini melanda dunia adalah kejadian baru. Kasus pertama dari pandemi saat ini dilaporkan di Wuhan di China pada Desember 2019. Pada laporan awalnya, virus tersebut bermanifestasi sebagai sekelompok kasus 
pneumonia, yang kemudian diidentifikasi disebabkan oleh virus corona baru. Organisasi Kesehatan Dunia (WHO) menamai virus tersebut sebagai COVID-19 pada 12 Januari 2020. Meskipun awalnya dilaporkan di China (dengan total 79.968 kasus dan 2.873 kematian pada Maret 2020), virus ini telah menyebar ke seluruh dunia yang dikonfirmasi di enam benua, (Johnson, 2020).

Orang-orang menjadi takut dan khawatir karena kurangnya pemahaman dan ketidakpastian. Ketika wabah disebabkan oleh virus baru, rumor dan informasi palsu menyebar dengan cepat. Stereotip cepat muncul terhadap orang yang memiliki atau mungkin memiliki penyakit. Seperti contoh misalnya, orang-orang Asia dicurigai atas halhal yang berkaitan dengan COVID-19. Juga, beberapa orang khawatir bahwa individu yang baru saja menyelesaikan karantina masih memiliki riwayat COVID-19 dan masih berpotensi menular. Menyalahkan orang yang terinfeksi dengan cara ini berpotensi dapat menyebabkan kemarahan, permusuhan. Ini dapat menciptakan kesulitan yang menghambat respons terhadap penyelesaian pandemi, (Elgohari et al., 2021). Sebagian alasan penyebarannya yang cepat dan jangkauannya yang luas adalah globalisasi dan keterkaitan dunia saat ini dibandingkan dengan jangkauan manusia awal dari pandemi sebelumnya. WHO dengan demikian menyatakan virus itu sebagai pandemi pada 30 Januari 2020.

Ketika virus terus menyebar, terlihat pengaruhnya terhadap kehidupan sosial dan sikap. Di antara langkah-langkah untuk mengekang penyebaran virus seperti yang disarankan oleh para profesional perawatan kesehatan adalah menjaga jarak sosial dan tinggal di rumah. Jarak sosial berarti memutus sebagian besar interaksi dan aktivitas sosial. Telah menunjukkan harapan dalam membatasi penyebaran virus, mereka juga memiliki dampak sosial negatif yang tidak diinginkan seperti munculnya perasaan "kesepian". Pasangan, keluarga, teman, dan kerabat harus tinggal terpisah sebagai ketaatan arahan dari pemerintah dan profesional perawatan kesehatan, yang pada dasarnya memotong orang dari dukungan sosial yang diperlukan. Berdasarkan pendapat Feeney, sejumlah besar penelitian mendukung teori dukungan sosial yang menunjukkan bahwa individu dengan integrasi sosial yang kuat dengan hubungan yang mendukung dan bermanfaat cenderung memiliki kesehatan mental dan kesejahteraan yang lebih baik. Sementara jaringan dukungan sosial yang kuat dapat berarti komunikasi yang konstan dalam jaringan dukungan sosial. Ini memiliki dampak yang jauh lebih besar dalam mengurangi perasaan "kesepian" daripada percakapan media sosial dan telepon/video yang terputus-putus bahwa jarak sosial dan langkah-langkah keamanan telah mengurangi interaksi sosial di masa pandemi saat ini.

Keberadaan virus corona (COVID-19) di Indonesia telah disikapi dengan berbagai kebijakan. Tercatat sejak 2020 perkembangan COVID-19, Pemerintah Indonesia menerapkan beberapa kebijakan diantaranya: 1) Pembatasan Sosial Berskala Besar (PSBB), 2) Penerapan protokol kesehatan (memakai masker, mencuci tangan pakai sabun, dan menjaga jarak, menghindari kerumunan), 3) Pembentukan kampung tangguh, 4) Membatasi mobilitas, 5) Melakukan swab saat bepergian dan keperluan sesuai 
ketentuan peraturan, 6) Vaksinasi, dan 7) Pemberlakukan Pembatasan Kegiatan Masyarakat (PPKM).

Selama perkembangan pandemi COVID-19, mengalami dinamika di kalangan masyarakat. Stigma direpresentasikan sebagai gambaran aib yang melekat dari satu orang atau komunitas terhadap orang tertentu. Orang-orang menstigmatisasi orang lain yang kemudian menimbulkan jarak sosial (social distancing). Atas pemberian stigma tersebut memberikan orientasi pada penerapan secara nasional yang dinamakan dengan protokol kesehatan (prokes). Pada kasus stigma penyakit menular, terdapat aib yang menyertai. Penyakit menular dapat mengancam kemampuan masyarakat, baik dengan membatasi orang yang terinfeksi dalam melakukan peran dalam masyarakat. Selain itu, penyakit menular yang menyebar dari anggota ke anggota melalui interaksi dipengaruhi oleh sifat sosial kelompok, (Elgohari et al., 2021).

Stigmatisasi dapat meningkatkan konsekuensi penyakit dalam banyak cara. Pertama, stigmatisasi dapat meningkatkan penderitaan pada pasien. Kedua, pasien mungkin menunda atau menghindari mencari konsultasi medis. Ketiga, para profesional dan sukarelawan yang bekerja di lapangan terutama bagi kalangan tenaga kesehatan dapat distigmatisasi yang menyebabkan stres dan kelelahan. Akhirnya, stigmatisasi dapat menimbulkan kerugian ekonomi yang cukup besar manakala orang menghindari kelompok atau seluruh wilayah yang terkait dengan COVID-19, (Elgohari et al., 2021).

Kemudian, mencermati perkembangan persebaran COVID-19 di Indonesia, untuk mengidentifikasi bahwa seseorang terkena COVID-19 atau tidak dilakukan melalui tes melalui hidung dan atau tenggorokan. Tes tersebut ada yang berupa antigen atau rapid test, PCR, dan antibodi. Meski masih menjadi perdebatan baik di kalangan tenaga medis atau masyarakat umum pada jenis tes tersebut, namun melalui tes tersebut masih digunakan untuk mendeteksi adanya COVID-19. Berdasarkan data nasional pada 10 (sepuluh) Oktober 2021 yang dilakukan pada rata-rata harian pada kurun waktu 7 (tujuh) hari melalui orang yang dites, positivitas, dan kasus kematian. Pada 172.000 orang yang dites (41.100 PCR/TCM dan 130.900 antigen) dengan tingkat positivitas sebesar $0.72 \%$. 


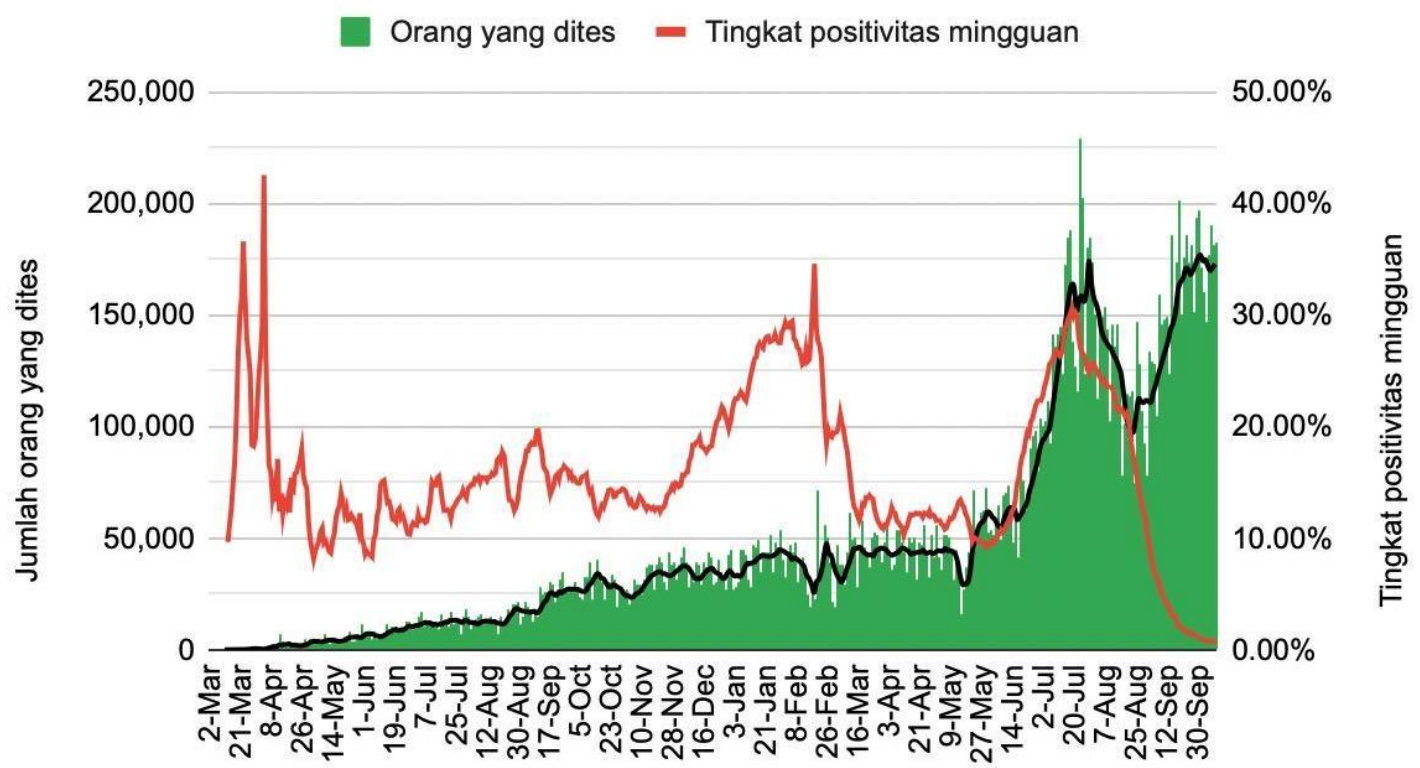

Sumber: KawalCOVID19

Selain dampak sosial dari COVID-19 adalah pengaruh psikologis yang telah dan akan terus terjadi pada individu. Sifat virus yang meluas berarti bahwa pemerintah harus menerapkan langkah-langkah kesehatan yang ketat untuk menahan virus. Beberapa tindakan termasuk mengunci sekolah, penutupan transportasi umum, dan langkahlangkah jarak sosial. Langkah-langkah ini telah menjadi sumber stres dan kecemasan bagi siswa, guru, pekerja, dan profesional perawatan kesehatan.

Situasinya berdampak bagi kelompok rentan seperti tunawisma, pengungsi, dan migran. Fakta bahwa virus ditularkan dari manusia ke manusia dan bahwa jarak sosial dan kebersihan yang layak adalah salah satu cara pencegahan. Seringkali kelompokkelompok ini tidak memiliki tempat berlindung dan satu-satunya yang tersedia adalah tempat yang penuh sesak, mereka kekurangan akses dalam penggunaan air untuk cuci tangan dan alat pelindung seperti masker dan sarung tangan.

Menyusul merebaknya virus, telah terjadi lonjakan jumlah kasus di beberapa daerah dan negara. Pembatasan lebih dari sekadar meregangkan temperamen dan kesabaran individu, meningkatkan konflik. Terjadi pula kasus sejenis seperti eskalasi konflik, tekanan pada keuangan, kehilangan pekerjaan, dan kegagalan/penutupan bisnis.

Kekhawatiran saat ini adalah menemukan obat dan vaksin untuk menghentikan penyebarannya dan mengobati kasus aktif. Meski begitu, pandemi memiliki dampak besar pada tatanan sosial dan psikologi. Ketakutan, kecemasan, peningkatan kasus kekerasan dalam rumah tangga, kematian, dan depresi adalah beberapa pengaruh utama pandemi.

Dengan perkembangan COVID-19 dan meningkatnya tantangan terhadap kesehatan dan kesejahteraan masyarakat, telah terjadi perubahan nyata dalam cara orang membincang tentang kesehatan mental. Kecemasan sebagai bagian tak terpisahkan pada kondisi sosial dan kini menjadi bagian dari wacana sehari-hari. Ini tercermin secara lokal dan internasional. Pada awal Mei 2020 Perserikatan Bangsa- 
Bangsa (PBB) menyampaikan tentang efek buruk dari isolasi sosial pada kesehatan mental penduduk. Orang berbicara tentang penyebab yang memperburuk: lebih banyak orang tinggal di rumah, tidak dapat mengakses aktivitas rutin yang digunakan untuk memelihara hubungan sosial (pertemuan keluarga, klub, konser, makan di luar) pengayaan (teater, bioskop) dan mengatasi stres (aktivitas fisik, olahraga, menghadiri tempat kebugaran). Namun, isolasi baru ini telah menjadi fenomena yang dialami bersama. Dampak dari pengalaman bersama ini telah dikurangi atau diperburuk sampai batas tertentu tergantung pada status ekonomi, kondisi kehidupan, akses ke sumber daya, karena faktor-faktor ini sering terkait, (Snider \& Flaherty, 2020).

Informasi yang tersedia terkait pandemi global coronavirus disease 2019 (COVID19) disambut dengan beragam tanggapan masyarakat Indonesia, sehingga menimbulkan berbagai stigma masyarakat. Disinformasi mengakibatkan kehati-hatian, kekhawatiran, dan ketakutan berlebihan yang tidak diimbangi dengan empati dan simpati kepada para korban. Pertama, seorang perawat, yang merawat pasien COVID-19 dan mengisolasi diri dari keluarganya, tidak diterima di lingkungannya karena takut tetangganya bahwa dia akan menyebarkan virus, meskipun dia menerapkan protokol alat pelindung diri (APD) COVID-19. Dalam kasus lain, beberapa perawat diusir dari rumah kontrakan mereka karena pemiliknya khawatir akan menulari dia. Kedua, pasien pertama di Indonesia ditemukan dan diumumkan oleh Presiden Republik Indonesia, pada 2 Maret 2020, yang menghebohkan publik yakni kekhawatiran terkait lonjakan penularan virus. Hingga April 2020, satu bulan setelah kasus pertama COVID-19 terdeteksi, lebih dari 8.000 kasus positif COVID-19 terkonfirmasi di Indonesia, (Sulistiadi, Rahayu, \& Harmani, 2020).

Stigmatisasi terhadap COVID-19 telah menjadi isu global yang memerlukan perhatian khusus. Stigma yang melekat pada pasien COVID-19, secara tidak langsung "memaksa" seseorang untuk menutupinya agar terhindar dari diskriminasi lingkungan sekitarnya. Termasuk menghindari untuk menghubungi tenaga kesehatan (nakes). Stigmatisasi COVID-19 juga dapat secara langsung atau tidak langsung meningkatkan penyebaran penyakit, (MacKenzie \& Smith, 2020). Agar perlindungan dan keselamatan orang yang terinfeksi COVID-19 dapat terjamin, pembuat kebijakan di setiap negara perlu mempertimbangkan langkah-langkah untuk melindungi pasien dari stigmatisasi (MacKenzie \& Smith, 2020).

Pemahaman yang salah, pengetahuan yang tidak lengkap tentang COVID-19, dan panduan yang membingungkan mengenai sosialisasi yang diberikan oleh pejabat publik mengakibatkan reaksi negatif terhadap petugas kesehatan, pasien COVID-19, dan keluarga pasien. Pemerintah berusaha meredam gejolak publik dengan kebijakankebijakan tertentu tetapi tidak memberikan informasi yang cukup untuk meningkatkan pemahaman publik. Di beberapa daerah, kasus stigma berkembang di sekitar pasien COVID-19, keluarga pasien, dan petugas kesehatan.

\section{Konsep Stigma}

Ketakutan dan ketidakpastian masa depan menambah ketakutan yang meningkat akan terjadinya krisis dalam rumah tangga-kekerasan dalam rumah tangga. Pedoman 
keselamatan yang bertujuan untuk membatasi penyebaran infeksi berarti bahwa lebih banyak orang (pasangan) menghabiskan lebih banyak waktu bersama. Meskipun menghabiskan lebih banyak waktu bersama seharusnya memiliki efek mendekatkan orang, hal itu juga berpotensi meningkatkan kekerasan dalam rumah tangga seperti yang terlihat ketika keluarga menghabiskan lebih banyak waktu bersama. Keluar dalam keadaan normal berarti pasangan menghabiskan lebih sedikit waktu bersama, yang mengurangi argumen dan konflik mereka. Namun, di bawah penguncian saat ini di beberapa daerah sebagai langkah-langkah keamanan untuk mengekang penyebaran virus.

Mengikuti model eskalasi konflik dari Friedrich Glasl (Jordan, 2015), menghabiskan lebih banyak waktu bersama dan menempatkan pasangan pada tahap eskalasi konflik ketiga yang konstan, yaitu "tindakan, bukan kata-kata". Di panggung, pihak-pihak yang terlibat dalam konflik percaya bahwa pembicaraan tidak menyelesaikan apa pun.

Stigma adalah atribut devaluasi yang memiliki konotasi negatif bagi orang yang distigmatisasi, menghasilkan diskredit yang terkait dengan kerugian (Goffman, 1974). Stigmatisasi pada umumnya ditujukan pada minoritas sosial tertentu, serta dikaitkan dengan masalah kesehatan pada penyakit yang secara tradisional, terutama karena ketidaktahuan, telah menimbulkan ketakutan dan kecurigaan, seperti AIDS atau masalah kesehatan mental. Menurut Ugidos, stigma dapat dibagi menjadi tiga komponen dalam interaksi konstan: stereotip (struktur pengetahuan tentang orang-orang dalam kelompok yang berbeda), prasangka (emosi negatif yang dihasilkan ketika stereotip diterapkan pada kelompok itu), dan diskriminasi (perilaku penolakan yang diarahkan pada kelompok/seseorang). Selain itu, memiliki banyak identitas atau peran sosial dapat menyebabkan diskriminasi interseksional, (Ugidos et al., 2020).

Merujuk pandangan McCall, kategori identitas yang berbeda dapat hidup berdampingan dan menyeberang ke individu yang sama, menimbulkan pengalaman dengan efek berlipat ganda karena interaksi. Di sisi lain, dimungkinkan juga untuk berbicara tentang stigma atau stigma diri yang terinternalisasi. Konsep ini mengacu pada stigma yang dirasakan setiap orang ketika menginternalisasi stereotip dan keyakinan tentang stigma yang terkait dengan berbagai kondisi, (Ugidos et al., 2020).

Saat ini, kemunculan pandemi COVID-19 baru-baru ini dan situasi sosial ekonomi dan kesehatan yang rumit yang ditimbulkannya di seluruh dunia dapat menjadi sumber stigmatisasi, karena sejumlah coronaphobiatelah muncul. Misalnya, orang yang baru saja didiagnosis dengan COVID-19 mungkin mengalami diskriminasi sosial dan menginternalisasi pemahaman dan menerapkannya pada diri mereka sendiri (Ugidos et al., 2020). Coronaphobia sebagai respons yang dipicu secara berlebihan dari ketakutan tertular COVID-19. Menyebabkan kekhawatiran yang menyertai gejala fisiologis dan stres. Hal ini dapat menimbulkan emosi prasangka terhadap diri sendiri, seperti perasaan bersalah, malu atau sedih, yang pada akhirnya akan mengondisikan perilaku mereka, (Arora, Kumar, Alat, \& Sekhar, 2020).

Sesuai dengan pokok kajian tersebut, penelitian ini bertujuan menganalisis pola berkembangnya stigma dan pola antisipasinya melalui pembentukan solidaritas kolektif. 


\section{Metode Penelitian}

Penelitian ini adalah untuk mengevaluasi dan mempromosikan pentingnya aspek psikologis dan sosial dalam konteks SARS-CoV-2. Yakni dalam menghadapi risiko stigma dan diskriminasi (SAD). Penelitian ini menggunakan pendekatan mixed method (Creswell, 2014). Pada pendekatan kuantitatif menggunakan analisis regresi untuk mengaitkan antara stigma, diskriminasi, kesehatan mental, dan kondisi sosial. Sedangkan pendekatan kualitatif, untuk menganalisis stigma sosial pada orang yang terkena COVID19 serta upaya pembentukan solidaritas kolektif dalam memberikan ketahanan.

Penelitian ini dilakukan pada masa pandemi COVID-19, sehingga peneliti tidak dapat melakukan wawancara tatap muka. Informasi primer diperoleh melalui pengamatan dan perbincangan warga masyarakat di wilayah Jawa Timur terhadap pandemi COVID-19. Yakni masyarakat yang mendapat stigma. Data diperoleh dari masyarakat rentan yakni tenaga kesehatan, orang tua, dan yang telah melakukan perjalanan luar kota. Untuk mengeksplorasi masalah yang terkait dengan COVID-19 dan untuk mengevaluasi persepsi dan pengalaman pasien COVID-19. Peneliti membingkai hasil pengamatan agar sesuai dengan konsep tahapan penelitian dan melakukan triangulasi informasi yang diberikan selama wawancara dengan informasi yang diperoleh dari sumber media online yang memiliki reputasi baik. Berikutnya, data sekunder diperoleh melalui berbagai pernyataan dari media massa online dan media sosial tentang stigma COVID-19, serta situs resmi perkembangan COVID-19 milik pemerintah.

Data penelitian diambil dari pengamatan, data primer (kuesioner, wawancara), dan data sekunder (studi dokumentasi, buku, jurnal, media online). Pada pendekatan kuantitatif dianalisis menggunakan aplikasi SPSS 16 , dan pada pendekatan kualitatif dianalisis menggunakan aplikasi Nvivo 12. Secara kualitatif memperoleh data berupa pemahaman stigma sosial dalam covid-19. Sedangkan secara kuantitatif memperoleh data korelasi stigma sosial, sikap mau/tidak untuk vaksin, dan kecemasan dari hasil COVID-19.

\section{Hasil dan Diskusi}

\subsection{Stigma sebagai Penghalang Keterlibatan Sosial}

Stigma dinyatakan sebagai gambaran standar yang disederhanakan dari "aib" orang-orang tertentu. Hadirnya ancaman bagi fungsi kelompok adalah dimulai dari proses stigmatisasi. Menurut Ahoursu (Mahmud \& Islam, 2021), percepatan penyebaran COVID-19 dan akibatnya telah membuat masyarakat menjadi takut, panik, khawatir, dan cemas. Dengan demikian, stigma cenderung sebagai penyakit sosio-psikologis. Pada berbagai faktor yang signifikan, perasaan ketidakamanan eksistensial dan sikap acuh tak acuh yang kuat dengan ketakutan yang menyebar dan perilaku pelabelan merupakan alasan utama untuk menumbuhkan stigma sosial pada pasien virus corona. Stigma sosial berupa diskriminasi, pelecehan, dan kebencian telah tersebar pada komunitas sosial karena sulit menentukan siapa yang membawa virus dan siapa yang tidak. Selain itu, terdapat ketakutan yang tidak proporsional, meningkatnya kurangnya pemahaman 
informasi, banyaknya informasi yang salah dan tidak adanya kepercayaan pada sistem kesehatan memicu munculnya stigma sosial, (Mahmud \& Islam, 2021).

Salah satu tantangan terbesar yang dihadapi orang yang mengalami masalah kesehatan mental adalah stigma, yang digambarkan oleh (Goffman, 1974) sebagai pengucilan dan pengurangan sosial seseorang berdasarkan sifat yang tidak diinginkan seperti yang ditemukan dalam pandangan negatif terkait dengan mereka yang berurusan dengan penyakit.

Stigma sosial didefinisikan oleh (Goffman, 1974) sebagai "atribut yang sangat mendiskreditkan". Ini menciptakan dikotomi antara "menjadi normal dan dapat diterima" versus "menjadi tercemar dan tidak diinginkan". Stigma sosial umumnya terkait dengan ras, budaya, jenis kelamin, kecerdasan dan kesehatan. Konseptualisasi stigma mengidentifikasi empat elemen yang berinteraksi satu sama lain: stigma yang diantisipasi, dirasakan, dialami, dan diinternalisasi. COVID-19 telah dikaitkan dengan semua elemen stigma sosial ini. Orang-orang mengubah tindakan mereka karena takut didiskriminasi, misalnya dengan menghindari tes SARS CoV-2 (stigma yang diantisipasi); pasien dan keluarganya merasa terhindar oleh orang lain (stigma yang dirasakan); orang yang terinfeksi atau terpapar oleh anggota rumah tangga dan/atau masyarakat mereka (mengalami stigma); dan beberapa pasien mungkin merasa malu dan menolak diri sendiri (stigma yang terinternalisasi). Orang yang terinfeksi SARS-CoV-2 dapat mengalami stigma yang berpotongan (multiple), misalnya ketika mereka juga termasuk dalam kelompok rentan, (Sotgiu \& Dobler, 2020).

Sikap dan bahasa ditemukan tidak hanya pada masyarakat umum tetapi juga, kadang-kadang, di antara para profesional perawatan kesehatan itu sendiri. Sementara kita telah lama berbicara tentang stigma yang berkaitan dengan berbagai penyakit seperti skizofrenia dan gangguan bipolar, jarang kita mengakui bahwa stigma ini meluas ke orang yang hidup dengan demensia. Dapat dikatakan bahwa stigma adalah penghalang terbesar untuk mengakses dan menggunakan layanan kesehatan, (Snider \& Flaherty, 2020).

Selain paparan stigma dari orang lain, orang yang mengalami gangguan juga dapat berkontribusi terhadap stigma itu sendiri. Stigma yang terinternalisasi, atau stigma diri dapat mengurangi harga diri dan kepercayaan diri seseorang. Berdampak pada bagaimana seseorang berperilaku dan bagaimana seseorang mencari bantuan saat terkena musibah. Stigma pada dasarnya adalah fenomena sosial yang berakar pada hubungan sosial dan dibentuk oleh budaya dan struktur masyarakat, (Snider \& Flaherty, 2020).

Pengetahuan yang tidak memadai dan informasi yang kontradiktif tentang penularan SARS-CoV-2 dan tindakan perlindungan, seperti mengenakan masker di depan umum, dikaitkan dengan kecemasan di kalangan penduduk. Ketidakpastian dan kecemasan masyarakat telah membuat mereka mempercayai informasi yang bias yang diberikan oleh media massa online, media sosial (misalnya Twitter, Facebook, Instagram). Informasi yang salah tentang COVID-19 telah menyebar dengan cepat di 
kalangan masyarakat (kadang-kadang melebihi kecepatan penyebaran pandemi COVID19 yang sebenarnya).

Selama masa-masa awal pandemi, identifikasi klaster infeksius, super spreader (mereka yang bertanggung jawab menginfeksi banyak orang) atau wabah komunitas menyebabkan ketakutan yang meluas di kalangan masyarakat. Ada spekulasi bahwa COVID-19 sama menularnya dengan campak dan dikaitkan dengan tingkat kematian kasus yang sangat tinggi. Gambar yang disiarkan di televisi menunjukkan mobil-mobil yang mengangkut peti mati korban COVID-19 mengingatkan pada epidemi virus Ebola Afrika Barat yang mematikan sekian tahun sebelumnya, (Sotgiu \& Dobler, 2020).

Kecemasan akibat penerapan lockdown yakni melalui PSBB (Pembatasan Sosial Berskala Besar) dan PPKM (Pemberlakuan Pembatasan Kegiatan Masyarakat) yang diselaraskan dengan tren COVID yang meningkat. Banyaknya ketidaktahuan seputar COVID-19, dan ketakutan akan tertular telah menimbulkan stigma di masyarakat setempat. Kasus indeks COVID-19 dan orang lain yang terinfeksi bersama dengan kontak dekat mereka yang diidentifikasi melalui aktivitas kesehatan masyarakat. Terdapat laporan media yang menggambarkan bagaimana petugas kesehatan garis depan telah distigma, dituding, dimarahi, yang menunjukkan ketidakterimaan pada penanganan di rumah sakit.

Gambaran stigma sosial yang meningkat diorientasikan pada seseorang saat melihat bahwa orang-orang yang secara sosial distigmatisasi dari kelompok sosial termasuk yang ditolak oleh rumah sakit setempat. Sebagaimana tempat pasien virus corona dirawat secara ketentuan satgas, dan sebaliknya mereka "dipaksa" melakukan karantina mandiri di tempat yang telah ditentukan seperti balai desa, gedung serbaguna, atau tempat yang luas untuk dapat menampung banyak pasien. Bersamaan dengan hal tersebut, stigma berkembang dari tempat-tempat yang rentan atas penyebaran COVID19. Stigma berdampak pada keadaan bahwa terdapat keluhan massal. Saat penyebaran COVID-19 mengalami peningkatan pada semua kabupaten/kota, banyak orang merasa panik dan akhirnya memunculkan sikap paranoid. Dari kendala psikologis tersebut, meski dianggap sebagai bentuk kehati-hatian dan kewaspadaan, telah berhasil menimbulkan kecurigaan-kecurigaan. Yakni saat berinteraksi di tempat umum, di tempat ibadah, dan tempat lain yang masih memungkinkan orang berjumpa dan berinteraksi. Karena gejala COVID-19 ditandai salah satunya adanya batuk, panas pada tubuh, akhirnya terdapat anggapan bahwa seseorang tersebut terkena COVID-19. Atas berkembangnya anggapan-anggapan tersebut dan saling dikonsumsi oleh masyarakat, mereka yang memiliki gejala tersebut merasa takut untuk melakukan rapid test baik yang antigen atau PCR.

Manakala seseorang ditetapkan positif COVID-19, maka orang yang positif COVID19 merasa takut, khawatir, bingung, sedih, dan perasaan-perasaan lain yang dapat mengganggu secara psikologis. Sedangkan dari orang lain berusaha untuk menghindari atau mendekati mereka yang positif COVID-19. Akhirnya ketergantungan utama bagi mereka yang positif COVID-19 adalah dengan tenaga kesehatan. Kemudian menimbulkan dampak sosialnya bahwa seseorang yang sebelumnya melakukan kontak fisik, 
berinteraksi, dikenai stigma bahwa orang tersebut berpotensi terkena COVID-19. Stigma tersebut dipertajam dengan kebijakan bahwa mereka harus menghindari interaksi dengan orang lain atau bahkan melakukan isolasi mandiri.

Isolasi mandiri dianggap sebagai cara untuk menghindarkan kontak fisik sekalipun itu dengan keluarga sendiri. Sekaligus upaya untuk memutus penyebaran COVID-19. Terlepas dari hal tersebut, adanya isolasi baik di rumah sakit atau mandiri berdampak pada stigma sosial seperti terkucilkannya dari lingkungan masyarakat, khawatir berinteraksi dengan orang lain pasca sembuh. Atas stigma tersebut, isolasi merupakan cara memisahkan orang sakit dan bukan orang sakit dari lingkungan sosial. Serta bentuk penundaan dalam melakukan tanggung jawab sosial.

Stigma menyerang aspek sosial-psikologis. Dalam hal ini terdapat kelompok rentan yang dinyatakan positif COVID yakni para lansia. Disaat mereka membutuhkan kasih sayang dari keluarga, dengan pengaturan isolasi dan semacamnya harus terjauhkan. Tidak boleh didekati, dijenguk, atau hal lain untuk menghibur pasien. Akibatnya pasien mengalami beban psikologis dari kondisi tersebut.

Dengan merebaknya pandemi COVID-19, orang yang terinfeksi dan dicurigai, dicap, distereotipkan, karena adanya keterkaitan yang dirasakan, dan oleh karena itu, meningkatnya stigmatisasi di antara masyarakat yang beragam. Semua praktik tradisional stigma sosial telah tenggelam di bawah kekuatan stigma sosial terkait COVID19. Akibat meningkatnya stigma sosial, berdampak pada kesejahteraan masyarakat dari segi jaminan sosial, jaminan kesehatan, penghidupan, hubungan sosial, bahkan keselamatan dalam penguburan jenazah. Dampak masif dari stigma sosial terkait COVID19 begitu menakutkan sehingga norma-norma sosial, nilai-nilai sosial, dan hubungan sosial, serta modal sosial sebelumnya dikalahkan dengan stigmatisasi, (Mahmud \& Islam, 2021).

Kelompok sosial pada lapis rentan seperti dokter profesional, tenaga kesehatan, dan petugas administrasi kesehatan tidak terhindarkan dari stigma sosial. Situasi yang paling rentan adalah "stigma rawan rumor" COVID-19 yang baru terbentuk, "stigma organisasi", "stigma komunitas", "stigma pekerja kantor" memperdalam jarak sosial, dan isolasi sosial. Berbagai bentuk stigma sosial itu, ikatan sosial yang telah terbentuk pada masyarakat seketika menyusut. Norma tradisional melalui solidaritas mekanis dalam komunitas pedesaan, dan bentuk modern solidaritas organik terlihat retak. Singkatnya, praktik stigma sosial yang tidak normal ini adalah tanggung jawab utama dari meningkatnya perampasan yang luar biasa terhadap pengobatan virus corona, pengobatan dari penyakit lain, dan krisis modal emosional dan sosial. Dengan demikian, stigma sosial terkait COVID-19 mengubah semua hubungan sosial menjadi satu hal "diri", tetapi "diri" ada tanpa kesejahteraan, dan dengan demikian masyarakat ada tanpa kerja sama, dan semua hubungan sosial buatan menghilang, (Mahmud \& Islam, 2021).

\subsection{Stigma Sosial Pasien COVID-19}

Stigma sosial, diskriminasi dan eksklusi telah dijelaskan secara rinci pada penyakit menular seperti TBC, HIV/AIDS. Stigma dan diskriminasi merusak tatanan sosial yang 
mengorbankan etika dan prinsip peradaban yang menjadi hak setiap individu. Mengenali sejarah stigma penyakit dapat memberi kita wawasan tentang bagaimana tepatnya, sikap stigmatisasi terbentuk, dan bagaimana sikap itu dibubarkan. Alih-alih hanya menyalahkan ketidaktahuan orang-orang yang mendukung sikap stigmatisasi tentang penyakit tertentu, harus memahami dengan tepat bagaimana sikap ini terbentuk sehingga dapat campur tangan dalam menangani, (Baldassarre et al., 2020). Istilah menghakimi tersebut memiliki kekuatan untuk mempengaruhi sikap dan perilaku, misalnya dengan mencegah pasien mencari pengobatan atau dengan mempengaruhi cara pembuat kebijakan memandang dan berusaha untuk mengatasi penyakit, (Sotgiu \& Dobler, 2020).

Kecemasan dan kekhawatiran akan dapat menyebabkan dua konsekuensi klinis dan kesehatan masyarakat yang berbahaya: keterlambatan pasien yang bergejala ke pelayanan kesehatan dan kurangnya deteksi individu yang menular (peningkatan penularan virus ke kontak yang rentan). Diagnosis yang tertunda telah dikaitkan dengan penyakit yang lebih parah, terutama pada orang tua dan kelompok rentan, sementara pemberitahuan yang tertunda dari pasien yang menular dapat memfasilitasi penyebaran cepat SARS-COV-2 di masyarakat.

Dengan perkembangan COVID-19 dan meningkatnya tantangan terhadap kesehatan dan kesejahteraan masyarakat, telah terjadi perubahan nyata dalam cara orang berbicara tentang kesehatan dan ketahan mental. Dengan kata lain, beberapa stigma telah berkurang, setidaknya untuk saat ini. Kecemasan dan depresi, sebagai bagian tak terpisahkan dari kehidupan di masa yang tidak pasti, kini lebih menjadi bagian dari wacana sehari-hari. Ini tercermin secara lokal tentang efek buruk dari isolasi sosial pada kesehatan mental penduduk. Orang berbicara tentang penyebab yang memperburuk: menjadi jauh lebih banyak tinggal di rumah, tidak dapat mengakses aktivitas rutin yang digunakan untuk memelihara hubungan sosial (pertemuan keluarga, klub, konser, makan di luar) pengayaan (teater, bioskop) dan mengatasi stres (aktivitas fisik, olahraga tim, menghadiri tempat kebugaran). Namun, sementara isolasi baru ini telah menjadi fenomena yang jauh lebih dialami "bersama", dialami oleh sebagian besar dunia sampai batas tertentu, dampak dari pengalaman bersama ini telah dikurangi atau diperburuk sampai batas tertentu tergantung pada status ekonomi, kondisi kehidupan, akses ke sumber daya, karena faktor-faktor ini sering saling terkait.

Pengendalian penyakit menular merupakan masalah kesehatan masyarakat yang penting. Meskipun penting untuk segera melakukan tindakan kesehatan masyarakat untuk mengurangi risiko penyebaran, itu bisa berakhir dengan tindakan pengendalian berdasarkan prinsip-prinsip ilmiah yang sehat. Dinamika "kita" versus "mereka" ini umum dalam stigmatisasi. Secara umum, dan menunjukkan cara di mana stigma penyakit dapat dilihat sebagai proxy untuk jenis ketakutan lain, terutama xenofobia dan ketakutan umum terhadap orang luar. Risiko pandemi yang terkait dengan infeksi SARSCOV-2 membuat pertimbangan antara lain, bagaimana stigma dan diskriminasi tetap menjadi hambatan serius untuk merawat orang yang diduga terinfeksi, terlebih lagi jika 
mereka adalah profesi pembantu, seperti petugas kesehatan, dipekerjakan dalam tanggap darurat, (Baldassarre et al., 2020).

Pada data berikut disajikan perkembangan jumlah pasien COVID-19 yang terpapar:

Gambar 2. Jumlah paparan COVID-19 (update 7 November 2021)

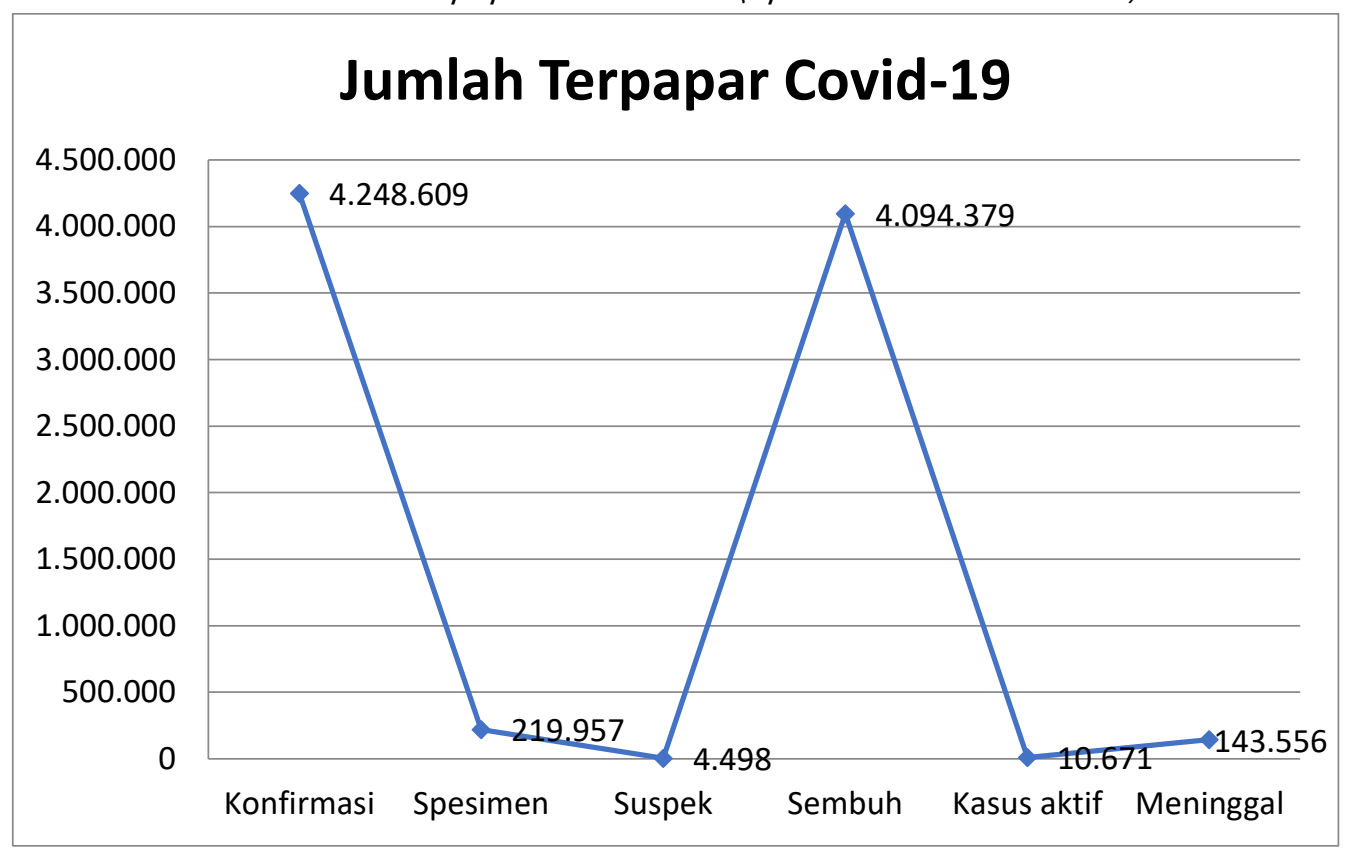

Sumber: COVID19.go.id (diolah oleh peneliti)

Dinamika yang terjadi di masyarakat mengalami beberapa perubahan. Sejak awal pandemi yang didukung dengan kebijakan pemerintah. Terdapat dua kecenderungan utama, yakni: kelompok yang mengalami stigma dan kelompok yang mengalami stigmatisasi.

Pertama, kelompok yang mengalami stigma meliputi: 1) orang yang telah bepergian, 2) penanggap darurat atau profesional kesehatan, dan 3) stigma menyakiti semua orang dengan menciptakan ketakutan atau kemarahan pada orang lain. Kedua, kelompok yang mengalami stigmatisasi dapat dikenai: 1) penghindaran atau penolakan sosial, 2) penolakan pada perawatan kesehatan, pendidikan, perumahan, atau pekerjaan, dan 3) kekerasan fisik (Villa et al., 2020).

Berikut disajikan analisis stigma yang dilihat dari beberapa aspek meliputi: diskriminasi, sakit, dampak stigma, faktor stigma, kelompok/komunitas, kesehatan, individu/personal, informasi (media), orang, diri, publik, respon masyarakat, kecemasan sosial, status, stigma, stigmatisasi. 


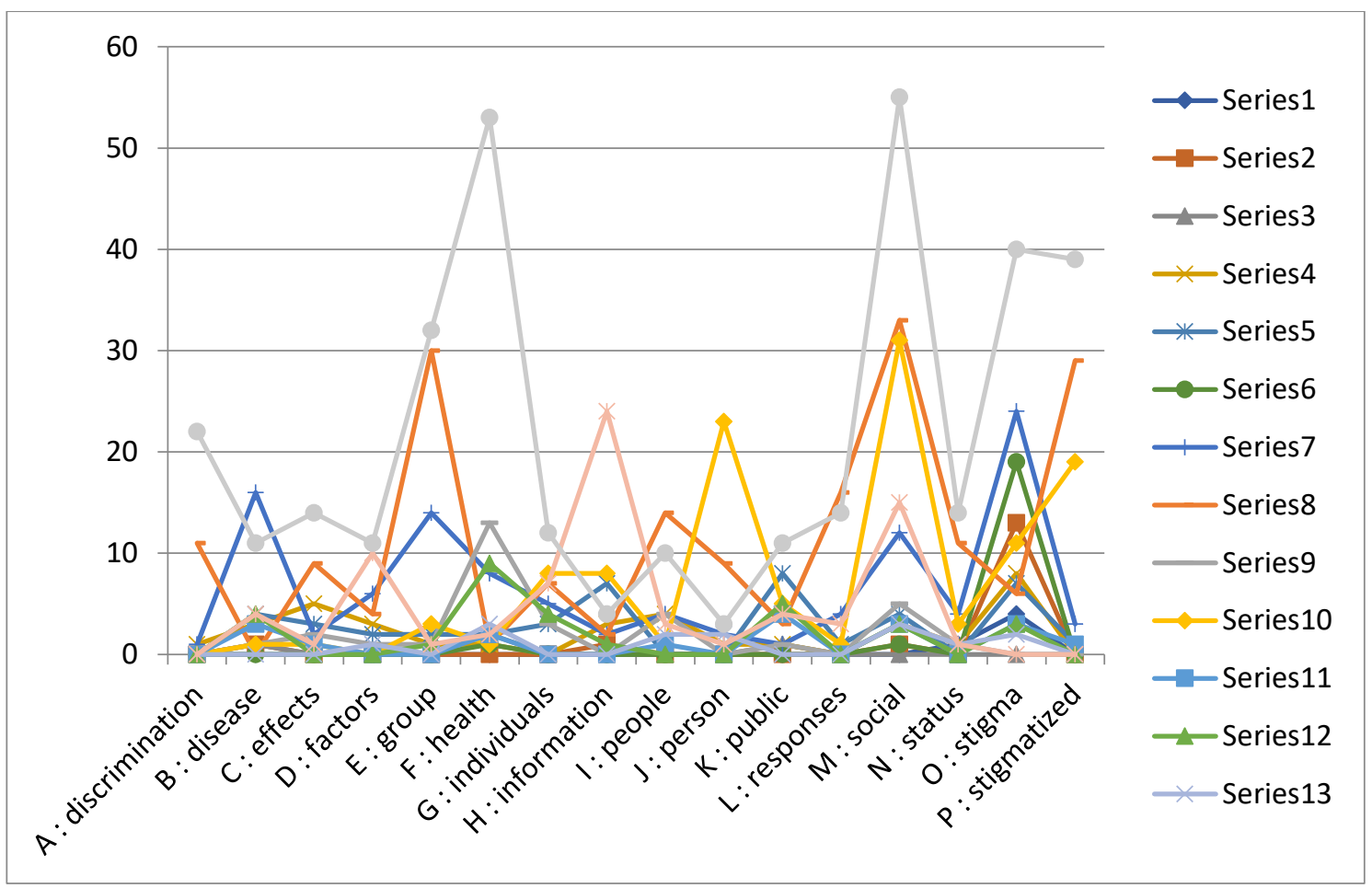

Sumber: Data Diolah Peneliti

Pada grafik tersebut pada stigma sosial unsur kesehatan (health) memiliki nilai 53, sosial memiliki nilai 55, dan stigma memiliki nilai 40. Artinya, tingkat stigma terkait COVID19 didasarkan pada tiga faktor utama: 1) COVID-19 merupakan penyakit baru dan masih banyak yang belum diketahui; 2) kita sering takut akan hal yang tidak diketahui; dan 3) ketakutan mudah dikaitkan dengan 'orang lain'. Stigma dapat merusak kohesi sosial dan mendorong terjadinya kemungkinan isolasi sosial terhadap kelompok, yang dapat berkontribusi pada situasi yang justru lebih memungkinkan, bukan mencegah, penyebaran virus. Hal ini dapat mengakibatkan masalah kesehatan yang lebih parah dan kesulitan mengendalikan wabah penyakit. Secara langsung dan tidak langsung dapat berpotensi: 1) Mendorong orang untuk menyembunyikan penyakitnya untuk menghindari diskriminasi, 2) Mencegah orang segera mencari perawatan kesehatan, dan 3) Mencegah mereka mengadopsi perilaku sehat.

Hal ini dapat membuat orang menjauh dari pemeriksaan, pengujian, dan karantina. Kami merekomendasikan bahasa 'mengutamakan manusia' yang menghormati dan memberdayakan orang di semua kanal komunikasi, termasuk media. Kata-kata yang digunakan di media sangat penting, karena akan membentuk bahasa dan komunikasi umum tentang virus corona baru (COVID-19). Pelaporan negatif berpotensi memengaruhi pandangan dan perlakuan terhadap orang yang diduga terjangkit coronavirus baru (COVID-19), pasien, keluarga, dan komunitas yang terkena dampak.

Tingkat stigma yang terkait dengan COVID-19 didasarkan pada tiga faktor utama: 1) merupakan penyakit baru; 2) kita sering takut akan hal yang tidak diketahui; dan 3) mudah untuk mengasosiasikan ketakutan itu dengan 'orang lain' (World Health 
Organization, 2020). Kemudian dari stigma tersebut, ruang lingkup tantangan yang ditimbulkan oleh ketidaksetaraan solidaritas, meliputi: tantangan solidaritas antargenerasi, solidaritas global, dan solidaritas antarkelompok (Stok, Bal, Yerkes, \& de Wit, 2021). Bagian sikap terhadap vaksin COVID-19 terdiri dari 6 pernyataan dengan skala Likert 5 poin $(5$ = sangat setuju, $4=$ setuju, $3=$ netral, $2=$ tidak setuju, $1=$ sangat tidak setuju), dengan pertanyaan tentang keraguan dan kekhawatiran tentang vaksin COVID19. Item pada bagian ini memiliki alpha sebesar 0,6 yang menunjukkan reliabilitas yang baik (El-Elimat, AbuAlSamen, Almomani, Al-Sawalha, \& Alali, 2021). Kepercayaan publik terhadap vaksin dan vaksinasi COVID-19 akan sama pentingnya dengan efektivitas vaksin itu sendiri. Bahwa pengalaman dengan COVID-19 akan membentuk kepercayaan pada vaksin lain untuk membangun kepercayaan diri (OECD, 2021). Sebagai variabel kontrol, dari 43 studi tentang perilaku kecemasan, menghasilkan perkiraan prevalensi keseluruhan kecemasan sebesar $25 \%$, yang bervariasi secara signifikan. Faktor risiko untuk perkembangan kecemasan termasuk fase awal atau puncak wabah, jenis kelamin perempuan, usia yang lebih muda, pernikahan, isolasi sosial, pengangguran dan status pelajar, kesulitan keuangan, tingkat pendidikan yang rendah, pengetahuan yang tidak memadai tentang COVID-19, epidemiologi atau risiko klinis penyakit dan beberapa variabel gaya hidup dan kepribadian (Javier Santabarbara; et.al, 2020). Berdasarkan unsur stigma sosial (X), kecemasan (kontrol), sikap mau vaksin/rapid test (kontrol), dan solidaritas kolektif $(\mathrm{Y})$. Berikut keterhubungan dari empat bagian tersebut.

Gambar 4. Analisis Stigma Sosial dan Solidaritas Kolektif pada COVID-19 dengan SPSS 16

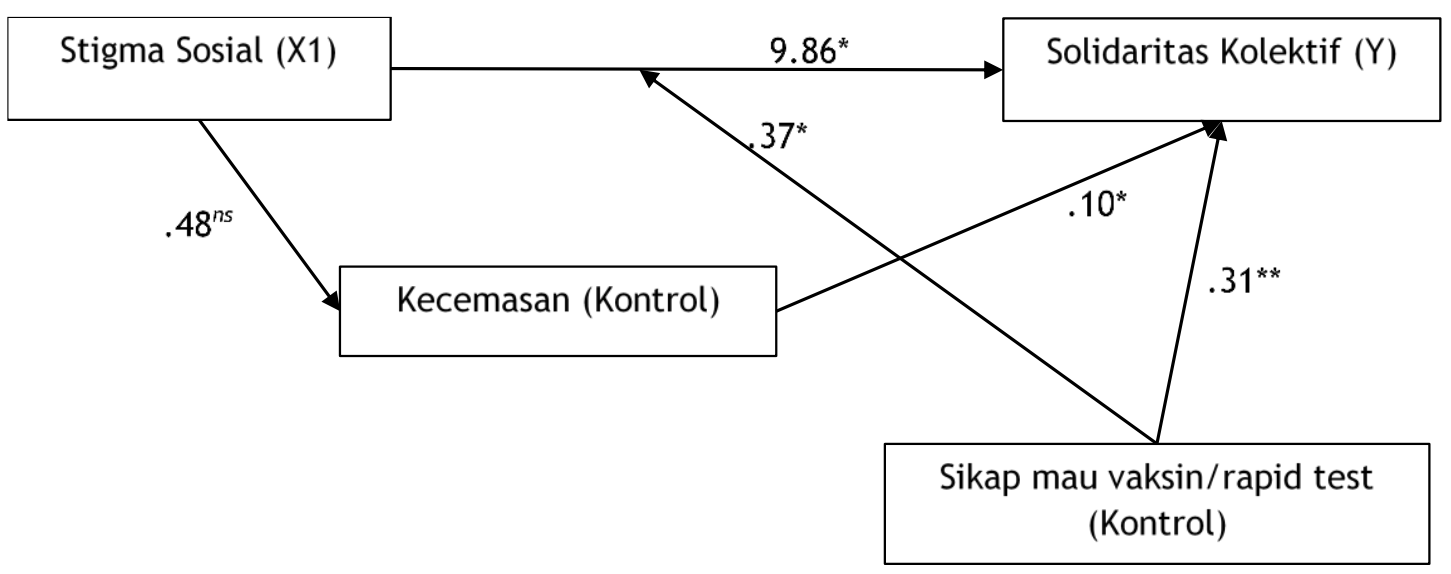

Sumber: Data Diolah Peneliti

Dari gambar 4 tersebut, diketahui terdapat keterkaitan dan signifikansi dari stigma sosial (X), kecemasan (kontrol), sikap mau vaksin/rapid test (kontrol), dan solidaritas kolektif $(\mathrm{Y})$. Berikut keterhubungan dari empat bagian tersebut. Dapat diberikan penekanan bahwa unsur tersebut memiliki keterkaitan dan solidaritas kolektif memiliki tingkat signifikansi dari tiga unsur lain.

\subsection{Pembentukan Solidaritas Kolektif}


Solidaritas kolektif juga dibangun melalui informasi yang jelas dan dapat ditindaklanjuti untuk mendukung komunitas dan orang-orang yang terkena dampak berupa: 1) penggunaan narasi yang simpatik, atau cerita yang memanusiakan pengalaman dan perjuangan individu atau kelompok yang terkena dampak virus corona baru (COVID-19); dan 2) komunikasi dukungan dan dorongan bagi mereka yang berada di garis depan (petugas kesehatan, relawan, tokoh masyarakat, dll.)

Untuk memeriksa pandemi dan stigma sosial, penguatan dan desentralisasi fasilitas medis COVID-19 termasuk pengujian, penelusuran, karantina, dan perawatan khusus virus corona di rumah sakit virus corona untuk semua harus dipastikan dengan mengalokasikan anggaran negara yang besar dan juga dengan mengambil inisiatif kemitraan publik-swasta untuk manajemen kesehatan. Melalui organisasi, baik organisasi kemasyarakatan, kepemudaan, formal, ataupun nonformal dan didukung dengan pemerintah setempat bersinergi agar dapat saling memotivasi orang-orang dari setiap komunitas untuk mendukung keluarga, penduduk setempat, dan tetangga mereka sebagai bentuk tanggung jawab moral (Mahmud \& Islam, 2021).

Orang dengan sumber daya pribadi yang lebih besar (pendapatan, pendidikan, dukungan sosial) dan kesehatan mental yang baik telah terbukti memiliki lebih banyak pengetahuan tentang penyakit menular yang muncul, tetap mengalami kekhawatiran meski cenderung tidak menstigmatisasi. Edukasi, komunikasi yang jelas dan jujur serta penggunaan bahasa yang tidak diskriminatif berpotensi meningkatkan pengetahuan, sikap dan perilaku terkait COVID-19 secara signifikan dan mengurangi stigma sosial. Komunikasi yang efektif mencakup informasi ahli tentang penyakit (misalnya penularan, jumlah orang yang didiagnosis, tingkat kematian, seroprevalensi di masyarakat, menunjukkan proporsi orang yang telah terinfeksi di beberapa titik di masa lalu, dll.) dan tindakan pengendalian infeksi yang direkomendasikan, (Sotgiu \& Dobler, 2020). Layanan kesehatan nasional, regional dan lokal yang berkomunikasi secara transparan dan bekerja dengan andal dan efisien juga dapat mengurangi ketakutan di kalangan masyarakat dan mengurangi stigmatisasi dan diskriminasi sosial. Contoh dari inisiatif yang berhasil untuk melawan miskonsepsi, misinformasi dan stigma adalah "pembentukan solidaritas kolektif". Dimana masyarakat secara langsung saling memberi dukungan, menjadi relawan, penciptaan lagu tentang COVID, pengajian-pengajian tentang hikmah pandemi, dan pemunculan humor-humor dapat menguatkan masyarakat serta menurunkan tingkat stigmatisasi pada pasien COVID-19.

\section{Kesimpulan}

Tingkat stigma terkait COVID-19 didasarkan pada tiga faktor utama: 1) COVID-19 merupakan penyakit baru dan masih banyak yang belum diketahui; 2) kita sering takut akan hal yang tidak diketahui; dan 3) ketakutan mudah dikaitkan dengan 'orang lain'. Stigma dapat merusak kohesi sosial dan mendorong terjadinya kemungkinan isolasi sosial terhadap kelompok, yang dapat berkontribusi pada situasi yang justru lebih memungkinkan, bukan mencegah, penyebaran virus. Hal ini dapat mengakibatkan masalah kesehatan yang lebih parah dan kesulitan mengendalikan wabah penyakit. 
Secara langsung dan tidak langsung dapat berpotensi: 1) Mendorong orang untuk menyembunyikan penyakitnya untuk menghindari diskriminasi, 2) Mencegah orang segera mencari perawatan kesehatan, dan 3) Mencegah mereka mengadopsi perilaku sehat.

\section{Saran}

Berikut beberapa bagian penting yang dapat dilakukan untuk menghindarkan pernyataan stigma sosial pada COVID-19:

1. Berbicara tentang orang-orang yang "menularkan COVID-19" "menginfeksi orang lain" atau "menyebarkan virus" karena menyiratkan penularan yang disengaja dan menyalahkan. Menggunakan terminologi yang mengkriminalisasi atau merendahkan martabat menciptakan kesan bahwa orang yang menderita penyakit telah melakukan sesuatu yang salah atau lebih rendah daripada kita semua, menimbulkan stigma, merusak empati, dan berpotensi memicu keengganan yang lebih luas untuk mencari pengobatan atau pemeriksaan, pengujian, dan karantina;

2. Mengulangi atau membagikan rumor yang belum dikonfirmasi, dan hindari menggunakan bahasa hiperbolik yang dirancang untuk menimbulkan ketakutan;

3. Menekankan atau memikirkan pesan negatif, atau ancaman. Kita perlu bekerja sama untuk membantu menjaga mereka yang paling rentan tetap aman;

4. Menyebarkan fakta: Stigma dapat diperparah oleh kurangnya pengetahuan tentang bagaimana virus corona (COVID-19) ditularkan dan diobati, dan bagaimana infeksi dicegah. Memprioritaskan pengumpulan, konsolidasi, dan penyebaran informasi yang akurat terkait negara dan komunitas tentang daerah yang terkena dampak, kerentanan individu dan kelompok terhadap COVID-19, pilihan pengobatan, dan tempat mengakses perawatan dan informasi kesehatan.

5. Melibatkan pemberi pengaruh sosial seperti para pemimpin agama dalam mengajak memikirkan tentang orang-orang yang distigmatisasi dan cara mendukung mereka, atau selebritas yang dihormati untuk memperkuat pesan yang mengurangi stigma. Informasi harus tepat sasaran dan selebriti yang diminta untuk mengomunikasikan informasi ini harus terlibat secara pribadi, dan sesuai dengan daerah dan budaya pendengar yang akan dipengaruhi.

6. Perkuat suara, cerita, dan gambar orang-orang lokal yang pernah mengalami virus corona baru (COVID-19) dan pulih atau yang mendukung orang yang dicintai melalui pemulihan untuk menekankan bahwa kebanyakan orang pulih dari COVID-19. Selain itu, laksanakan kampanye "pahlawan" untuk menghormati perawat dan petugas kesehatan yang mungkin mengalami stigma. Relawan komunitas juga berperan besar dalam mengurangi stigma di masyarakat.

7. Menekankan upaya untuk menemukan vaksin dan pengobatan dapat meningkatkan ketakutan dan memberi kesan bahwa kita tidak berdaya menghentikan infeksi saat ini. Sebaliknya, promosikan konten seputar praktik pencegahan infeksi dasar, gejala COVID-19, dan kapan harus mencari perawatan kesehatan. 


\section{Daftar Pustaka}

Arora, A., Kumar, A., Alat, P., \& Sekhar, S. (2020). Understanding coronaphobia. Asian Journal of Psychiatry, 54, 1-6.

Baldassarre, A., Giorgi, G., Alessio, F., Lulli, L. G., Arcangeli, G., \& Mucci, N. (2020). Stigma and Discrimination (Sad) at the Time of the Sars-Cov-2 Pandemic. International Journal of Environmental Research and Public Health, 17(17), 129. https://doi.org/10.3390/ijerph17176341

Creswell, J. W. (2014). RESEARCH DESIGN: Qualitative, Quantitative, and Mixed Methods. In Sage Publications, Inc. (Vol. 53). https://doi.org/10.1017/ CB09781107415324.004

El-Elimat, T., AbuAlSamen, M. M., Almomani, B. A., Al-Sawalha, N. A., \& Alali, F. Q. (2021). Acceptance and attitudes toward COVID-19 vaccines: A cross-sectional study from Jordan. PLOS ONE, $16(4$ April), 1-15. https://doi.org/ 10.1371/journal.pone.0250555

Elgohari, H. M., Bassiony, M. M., Sehlo, M. G., Youssef, U. M., Ali, H. M., Shahin, I., ... Mahdy, R. S. (2021). COVID-19 Infection Stigma Scale: psychometric properties. Egyptian Journal of Neurology, Psychiatry and Neurosurgery, 57(1). https://doi.org/10.1186/s41983-021-00317-0

Goffman, E. (1974). Stigma; Notes on the management of spoiled identity. Jason Aronson, New York, N.Y., (147 p.) S. https://doi.org/10.2307/2575995

Javier Santabarbara; et.al. (2020). Prevalence of anxiety in the COVID-19 pandemic: An updated meta-analysis of community-based studies. Progress in Neuropsychopharmacology \& Biological Psychiatry, (January).

Johnson, M. (2020). Novel Coronavirus - 2019-nCoV. Materials and Methods, 10(JANUARY), 1-5. https://doi.org/10.13070/mm.en.10.2867

Jordan, T. (2015). Glasl's Nine - Stage Model Of Conflict Escalation. 1-7.

MacKenzie, J. S., \& Smith, D. W. (2020). COVID-19: A novel zoonotic disease caused by a coronavirus from China: What we know and what we don't. Microbiology Australia, 41(1), 45-50. https://doi.org/10.1071/MA20013

Mahmud, A., \& Islam, M. R. (2021). Social Stigma as a Barrier to Covid-19 Responses to Community Well-Being in Bangladesh. International Journal of Community Well-Being, 4(3), 315-321. https://doi.org/10.1007/s42413-020-00071-w

OECD. (2021). Enhancing public trust in COVID-19 vaccination: The role of governments. OECD Science, Technology and Industry Policy Papers, (May), 127.

Snider, C. J., \& Flaherty, M. P. (2020). Stigma and mental health: The curious case of COVID-19. Mental Health: Global Challenges Journal, 3(1), 27-32. https://doi.org/10.32437/mhgcj.v3i1.89

Sotgiu, G., \& Dobler, C. C. (2020). Social Stigma in the Time of Coronavirus Disease 2019. European Respiratory Journal, 56(2), 23-25. https://doi.org/10.1183/ 13993003.02461-2020

Stok, F. M., Bal, M., Yerkes, M. A., \& de Wit, J. B. F. (2021). Social inequality and 
solidarity in times of covid-19. International Journal of Environmental Research and Public Health, 18(12). https://doi.org/10.3390/ijerph18126339

Sulistiadi, W., Rahayu, S., \& Harmani, N. (2020). Handling of public stigma on covid19 in Indonesian society. Kesmas, 15(2), 70-76. https://doi.org/ 10.21109/KESMAS.V1512.3909

Ugidos, C., López-Gómez, A., Castellanos, M. Á., Saiz, J., González-Sanguino, C., Ausín, B., \& Muñoz, M. (2020). Evolution of intersectional perceived discrimination and internalized stigma during COVID-19 lockdown among the general population in Spain. International Journal of Social Psychiatry. https://doi.org/10.1177/0020764020975802

Villa, S., Jaramillo, E., Mangioni, D., Bandera, A., Gori, A., \& Raviglione, M. C. (2020). Stigma at the Time of the COVID-19 Pandemic. Clinical Microbiology and Infection.

World Health Organization. (2020). Stigma Sosial Terkait Dengan COVID-19. Unicef, 1-5. Retrieved from https://www.who.int/docs/defaultsource/searo/indonesia/covid19/panduan-untuk-mencegah-dan-mengatasistigma-sosial.pdf?sfvrsn=4f8bc734_2\#: :text=APA DAMPAKNYA\%3F,\%2C bukan mencegah $\% 2 \mathrm{C}$ penyebaran virus. 